\title{
Restrukturisasi Independensi Hakim dalam Sistem Peradilan Pidana yang Berwawasan Pancasila
}

\author{
M. Ramzi Maulana*, Pujiyono \\ Universitas Diponegoro dan Jl. Imam Bardjo, Pleburuan, Kota Semarang \\ *Correspondence email: m.ramzimaulana0@gmail.com
}

\begin{abstract}
Abstrak. Kedudukan kekuasaan kehakiman berada di luar kekuasaan eksekutif dan legislatif. Penempatan ini bisa dimaksudkan agar hakim tidak menggunakan kekuasaannya untuk menindas orang secara semena-mena dan tidak membuat aturan hukum yang dapat merugikan masyarakat. Hakim saat ini berada di bawah kekuasaan kehakiman yang netral dan bebas dari pengaruh kekuasaan lain serta memiliki sikap independen dalam bersidang tanpa intervensi dari kekuasaan eksekutif dan legislatif. Tujuan dari penelitian ini adalah untuk mengetahui realitas kemandirian hakim dalam memberikan putusan dan menilai orang yang berselisih serta melihat bagaimana pengaruh nilai-nilai Pancasila terhadap hakim dalam memberikan putusan berdasarkan nilainilai yang terkandung dalam Pancasila, sehingga mereka dapat memberikan keadilan berdasarkan hukum yang hidup di masyarakat. . Metode dalam penelitian ini menggunakan pendekatan normatif yang menjadi sumber acuan penelitian ini dengan menggunakan pendekatan literatur, pendekatan konseptual dan pendekatan nilai. Hasil penelitian menunjukkan bahwa saat ini kedudukan hakim secara mandiri masih terbatas, mengingat dalam memutus perkara sengketa pidana dengan cara pidana, hakim tidak memutus berdasarkan nilai-nilai yang terkandung dalam Pancasila. Hal ini dibuktikan dengan keterbatasan hakim dalam memutus perkara, dimana secara individu hakim tidak dapat memberikan putusan sesuai dengan hati nuraninya bahkan terkendala oleh peraturan perundang-undangan yang tertulis. Hal ini menunjukkan kebebasan pribadi hakim seolah-olah terikat oleh tuntutan dan tuntutan yang diberikan oleh jaksa penuntut umum. Berangkat dari kondisi tersebut, maka diperlukan penataan kembali kemandirian lembaga peradilan dalam mengadili dan memutus perselisihan yang harus didasarkan pada wawasan Pancasila. Hal ini dimaksudkan agar peradilan menjadi lembaga yang mandiri berdasarkan budaya hukum Pancasila yang lebih religius, kemanusiaan, dan berkeadilan berdasarkan nilai-nilai yang hidup dalam masyarakat.
\end{abstract}

Kata kunci: Sistem Peradilan Pidana; Kekuasaan Kehakiman; Independensi; Pancasila

Abstract. The position of judicial power is outside the executive and legislative powers. This placement can be intended so that the judge does not use his power to oppress people arbitrarily and does not make legal rules that can injure the community. Currently, judges are under judicial power which is neutral and free from the influence of other powers and has an independent attitude in hearing without intervention from the executive and legislative powers. The purpose of this research is to find out the reality of the independence of judges in giving decisions and judging people who are in dispute and see how the influence of Pancasila values on judges in giving decisions based on the values contained in Pancasila, so that they can provide justice based on the laws that live in society. The method in this study uses a normative approach, which is the reference source of this study using the literature approach, conceptual approach and value approach. The results of the research show that currently the position of judges independently is still limited, considering that in deciding criminal dispute cases using penal means, judges do not decide based on the values contained in Pancasila. This is proven by the limitations of judges in deciding a case, where individually a judge cannot give a decision according to his / her conscience and is even constrained by the written rules of the law. This shows as if the judge's personal freedom is bound by the demands and charges given by the public prosecutor. Departing from this condition, it is necessary to rearrange the independence of the judiciary in adjudicating and deciding disputes which must be based on the Pancasila insight. This is intended so that the judiciary becomes an independent institution based on the Pancasila legal culture that is more religious, humanitarian, and justice based on the values that live in society.

Keywords: Criminal Justice System; The Judiciary; Independence; Pancasila

\section{PENDAHULUAN}

Pada dasarnya negara Indonesia merupakan negara hukum sebagaimana dikatakan di dalam UUD 1945 pasal 1 ayat (3) "negara Indonesia adalah negara hukum". Berangkat dari substansi yang ada di dalam UUD tersebut terdapat sedikit kandungan yang bermakna bahwa Negara mengedepankan ajaran dan prinsip-prinsip tentang supremasi hukum, di mana hukum bisa dijadikan rujukan dan pedoman dalam menjalankan kehidupan dan arah penetapan kebijakan yang bias menjadi solusi bagi masyarakatnya. ${ }^{1}$ Perwujudan nilai yang ada di dalam pembukaan UUD 1945 bisa dijadikan sumber dalam menentukan hukum seperti apa yang akan diterapkan kedepannya. Mengingat selama ini hukum dijadikan sumber sarana untuk menertibkan masyarakat dan mengatur lembaga peradilan supaya tidak melanggar norma yang ada. Salah satu ciri Negara hukum adalah menjadikan kekuasaan

${ }^{1}$ Darmoko Yuti Witanto dan Arya Putra Negara Kutawaringin., Diskresi Hakim Sebuah Instrumen Menegakkan Keadilan Substantif Dalam Perkara-Perkara Pidana, (Bandung, Alfabeta, 2013), hlm. 1. 
yang berada pada setiap badan-badan Negara sehingga terbentuk ciri dari Negara yang disebut sebagai Negara hukum (rule of law).

Sistem Peradilan Pidana bias bermakna suatu sistem dalam mengendalikan tindak pidana yang akan dilakukan dengan menempatkan badan-badan Negara yang ada di dalamnya seperti adanya lembaga kepolisian, Kejaksaan, Pengadilan dan permasyarakatan terpidana. $^{2}$ Keberadaan lembaga kepolisian bisa mempengaruhi para pelaku kejahatan untuk tidak melakukan kejahatan disebabkan ketakutan pelaku kejahatan dalam proses peradilan yang akan dijalaninya. Dari sekian system peradilan pidana yang ada di dalamnya, terdapat satu lembaga yang memiliki peran yang sangat besar yaitu pengadilan. Lembaga pengadilan dipimpin oleh lembaga Kekuasaan Kehakiman, dimana lembaga tersebut menjadi dasar penentuan seorang pelaku kejahatan dianggap bersalah. Mengacu dari proses system peradilan maka dapat dikatakan bahwa dalam menentukan hukuman bagi pelaku kejahatan harus berdasarkan proses panjang system peradilan pidana, bahkan bisa menjadi dasar penanggulangan kejahatan. ${ }^{3}$ Penanggulangan bisa dimaknai dengan pengendalian tindak pidana supaya masyarakat selalu berada dalam pengawasaan dan batasan-batasan yang telah disepakati masyarakat. Bentuk dari toleransi yang diberikan masyarakat terhadap pelaku kejahatan adalah hukuman, sehingga dengan adanya penghukuman bisa memberikan kesadaran bagi pelaku kejahatan untuk tidak melakukan kejahatan yang sama. Boleh dikatakan kejahatan tidak akan pernah mati selama ada masyarakat. Salah satu cara untuk menanggulangi kejahatan yang terjadi di masyarakat adalah melalui sistem peradilan pidana. Meskipun penanggulangan kejahatan melalui sistem peradilan pidana saat ini masih di pertanyaankan disebabkan oleh para pelaku penegak hukum yang tidak memiliki independensi, sehingga menimbulkan stigma kurang baik di masyarakat.

Pertemuan yang di adakan pada International Commission of Jurists di Bangkok pada tahun 1965 dipelopori terkait konsep negara hukum yang modern, yang di maknai sebagai "the dynamic aspects of the Rule of Law in the modern age" (aspek-aspek dinamika aturan hukum dalam abad modern). Pada konferensi yang diselenggarakan tersebut dikatakan bahwa ada 6 (enam) syarat-syarat dasar untuk terselenggaranya pemerintah

2 Mardjono Reksodiputro, Sistem Peradilan Pidana Indonesia (Melihat Kepada Kejahatan Dan Penegakan Hukum Dalam Batas-Batas Toleransi), (Jakarta: Fakultas Hukum Unversitas Indonesia, 1993), Hlm. 1

${ }^{3}$ Romli Atmasasmita, Sistem Peradilan Pidana(Criminal Justice System) Perspektif Eksistensialisme Dan Abolisionalisme, (Jakarta: Penerbit Bina Cipta,1996), HIm. 15. yang demokratis di bawah Rule of $\mathrm{Law}^{4}$, disebutkan di antaranya adalah peradilan atau badan-badan kehakiman yang independen dan tidak condong ke pihak manapun. Bebas dalam artian tidak ada satupun keterikatan dan batasan dalam memutuskan sesuatu. Mengingat di dalam sistem peradilan banyaknya terjadi perubahan diakibatkan karena proses penegakan hukum yang kurang jujur, sehingga kebebasan hakim terkadang bisa berubah sesuai dengan berjalannya sistem peradilan tersebut. Maka sangat wajar di dalam sistem peradilan pidana peran hakim sangat krusial dalam menentukan baik atau buruknya suatu sistem peradilan, karena orang hanya melihat dari hasil putusan yang diberikan.

Ketertidakpihakan lembaga peradilan pidana bisa mendatangkan peradilan yang adil (independent and impartial judiciary) Negara hukum berhak memiliki independensi seperti ini yang terkhususnya pada lembaga kehakiman sebagai satu dari lembaga negara yang senantiasa dituntut untuk menegakkan hukum yang seadil-adilnya, demi ketertiban dan kepastian hukum yang akan didapatkan oleh masyarakat. Perwujudan dalam penegakan hukum yang dicita-citakan itu, dengan demikian seorang hakim dalam memeriksa, menuntut, dan membuat suatu keputusan dalam suatu perkara harus dapat melindungi dan diberi kekuasaan yang merdeka dan bebas oleh negara, sehingga tidak ada sedikitpun intervensi dari pihak manapun baik yang memiliki kekuasaan ataupun hubungan kekeluargaan. Perindungan yang diberikan Negara terhadap pihak kehakiman memberikan keleluasaan bagi hakim dalam memutuskan perkara tidak terikat dengan apapun baik itu ancaman ataupun gangguan dari kekuasaan. Adanya jaminan seperti ini bisa menghadirkan ketidakberpihakan hakim kecuali terhadap hukum dan keadilan demi terselenggaranya negara hukum Republik Indonesia. Seperti kita mengetahui bahwa amanah dari UUD 1945 adalah menghadirkan kebebasan dan keleluasaan kepada hakim dalam menjatuhkan putusan tanpa ada intervensi ataupun karena adanya kepentingan yang di bela. Misalkan sebagaimana disebutkan di dalam Pasal 24 ayat (1) UUD 1945 menegaskan bahwa: "Kekuasaan kehakiman merupakan kekuasaan yang merdeka untuk menyelenggarakan peradilan guna menegakkan hukum dan keadilan".

Hakim dalam menjalankan tugasnya sebagai penegak hukum tidak bisa dipengaruhi oleh factor politik dan ekonomi. Factor politik yang dimaksudkan disini adalah seorang hakim ketika ingin direkrut tidak boleh berasa dari partai politik, sedangkan factor ekonomi telah dipenuhi dengan memberikan gaji yang cukup mumpuni supaya tidak tergiur dengan materi dari pihak manapun. Hakim dari lembaga kekuasaan yang diakui oleh Negara juga dipisahkan dari kekuasaan

4 Miriam Budiardjo, Dasar-Dasar Ilmu Politik, (Jakarta: Gramedia Pustaka Utama), Edisi revisi: Cetakan kelima, Hlm. 60 
eksekutif dan juga legislative, dimana hakim digolongkan ke dalam kekuasaan yudikatif, sehingga tidak bisa dipengaruhi oleh pihak eksekutif dan juga legislative. Seorang hakim dalam menjalankan tugas nya tidak boleh berdasarkan kepentingan penguasa atau orang berpengaruh lainnya, melainkan hakim dalam menegakkan keadilan harus berdasarkan kebenaran semata. Seperti contohnya kekuasaan yang diberikan kepada hakim yaitu seorang hakim harus menyelenggarakan persidangan secara terbuka sehngga tidak ada sesuatu apapun yang ditutupi dari pandangan masyarakat supaya dalam menjatuhkan hukuman tidak ada sesuatu yang disembunyikan. Disini hakim harus menghayati nilai-nilai keadilan yang hidup di tengahtengah masyarakat. Hakim dalam menjalankan tugasnya bukan hanya sebagai mulutnya undang-undang atau peraturan perundang-undangan, melainkan juga sebagai "mulut" keadilan yang menyuarakan perasaan keadilan yang hidup di tengah-tengah masyarakat. ${ }^{5}$ Disini jelas menunjukkan bahwa seorang hakim dalam memutuskan perkara haruslah berdasarkan keadilan. Seiring perubahan nilai yang ada pada masyarakat terkadang bisa mendapatangkan permasalahan hukum yang baru didalamnya, dimana untuk saat ini seorang hakim lebih terkekang dengan aturan yang tertutis saja. Mengingat selama ini Negara Indonesia masih memberlakukan KUHP peninggalan colonial belanda yang lebih berorientasi pada nilai kepastian semata, sehingga hakim tidak memiliki kebebasan dalam menentukan pilihan dalam menentukan pilihan hukum yang akan diberikan kepada pelaku kejahatan. Padahal kita mengetahui sendiri bahwa dalam Undang-Undang kekuasaan kehakiman disebutkan Pasal 5 ayat (1) juga menjelaskan "Hakim dan Hakim Konstitusi wajib mengali, mengikuti dan memahami nilai-nilai hukum dan rasa keadilan yang hidup dalam masyarakat". Menggali yang dimaksud disini adalah melihat hukum bukan hanya tertera dalam undang-undang, namun juga harus melihat aspek yang ada disekitar masyarakat. Pencarian dengan melihat nilai-nilai yang hidup di masyarakat merupakan bagian dari amanah undang-undang kekuasaan kehakiman tersebut. Jika hukum yang digali sudah ditemukan, maka seorang hakim harus memutuskan perkara berdasarkan nilai-nilai yang hidup di masyarakat. ${ }^{6}$ Seperti misalkan peristiwa yang terjadi pada mbok Minah, dimana beliau diputuskan bersalah karena telah mencuri. Jika kita menggali nilai yang hidup di masyarakat tersebut menunjukkan bahwa perbuatan mbok Minah merupakan kebiasaan masyarakat setempat yang oleh masyarakat

5 Jimly Asshiddiqie, Gagasan Negara Hukum Indonesia, (Jakarta, Konstitusi Press, 2005), Hlm. 11-12

${ }^{6}$ Abdul Manan, Penemuan Hukum Oleh Hakim dalam Praktek Hukum Acara di Peradilan Agama. Makalah yang disampaikan pada Acara Rakernas Mahkamah Agung Rl tanggal 10 s/d 14 Oktober 2010, di Balikpapan, Kalimantan Timur. tersebut hanya melihat sebagai perbuatan biasa, bukan merupakan bagian dari tindak pidana.

Hakim sebagai penegak hukum yang mengadili suatu perkara harus memeriksa dan memutuskan sesuatu perkara khususnya pidana berdasarkan kemauan dari para penuntut umum. Mengingat selama ini, dalam system peradilan pidana saat ini, jaksa sebagai pembela dari korban sedangkan pengacara sebagai pembela dari terdakwa. Disini menunjukkan bahwa seorang hakim hanya bias memutuskan perkara yang terikat dari dakwaan dan pembelaan dari jakda dan pengacara. Hakim tidak memiliki kewenangan tersendiri dalam memberikan putusan yang sesuai dengan hat nurani serta lebih mengedepankan niai-nilai yang terkandung di pancasila. Pancasila memiliki beberapa aspek nilai yang terkandung di dalamnya seperti misalnya aspek ketuhanan, kemanusiaan dan keadilan.

Beranjak dari permasalahan yang telah penulis paparkan, maka dapat dilihat dari beberapa aspek kajian yang akan di bahas selanjutnya, yang berupa Realitas dari lembaga kehakiman dalam memberikan putusan hukuman terhadap terdakwa saat ini dan adanya Restrukturisasi terhadap kebebasan hakim dalam menerapkan hukuman yang lebih bersifat nilai-nilai pancasila dalam menjatuhkan hukuman bagi terdakwa, sehingga bisa tetap terjaga independensi hakim dalam melaksakan tugas dan fungsinya sesuai dengan nilai yang terkandung di dalam pancasila.

\section{METODE}

Berdasarkan permasalahan yang telah penulis paparkan di atas, maka untuk menjawab permasalahan dan mengkaji penelitian ini, penulis menggunaan metode pendekatan Normatif. Penelitian hukum normative lebih bersifat kajian yang melihat aturan perundang-undangan sebagai tingkah laku di dalam masyarakat. Pokok kajian di dalam pendekatan normative hanya mengaji melalui pendekatan undang-undang, pendekatan konseptual, serta pendekatan perbandingan. ${ }^{7}$

Pendekatan Normatif melihat hukum yang dikonsepkan sebagai norma atau kaidah yang belaku dalam masyarakat dan menjadi acuan perilaku setiap orang, sehingga dalam kajian normative lebih mengkaji aturan perundang-undangan yang disesuaikan dengan praktek dilapangan. Pendekatan perundangundangan lebih mengkaji hukum baik yang bersifat formil dan non formil, sedangkan pendekatan konseptual lebih meninjau hukum berdasarkan asas-asas, doktrin da juga nilai-nilai yang terkandung di dalamnya.

Penggunaan metode pendekatan undang-undang atau lebih dikenal dengan yuridis dan konseptual dimaksud untuk menjawab permasalahan yang terkait dengan Restrukturisasi Independensi Hakim dalam Memutuskan Suatu Perkara Berdasarkan Nilai-Nilai

7 Abdulkadir Muhammad, Hukum dan Penelitian Hukum, (Bandung: PT. Citra Aditya Bakti, 2004), hlm. 52 
M. Ramzi Maulana dan Pujiyono, Restrukturisasi Independensi Hakim dalam Sistem Peradilan Pidana yang Berwawasan Pancasila

Pancasila. Dalam pendekatan ini lebih melihat pengaturan undang-undang nomor 48 tahun 2009 yang tidak sesuai dengan praktek yang dilakukan seorang hakim.

\section{HASIL DAN PEMBAHASAN \\ Realitas Independensi Lembaga Kehakiman dalam Mengadili terdakwa dalam Sistem Peradilan Pidana Saat Ini}

Kata independen diartikan di dalam kamus besar bahasa Indonesia adalah tidak terikat, merdeka atau bebas. Pengguanaan istilah independen dalam penegakan hukum berarti menempatkan kebebasan tanpa adanya intervensi dari pihak manapun dalam menegakkan hukum. Syarat suatu bangsa dikatakan memiliki independen disebabkan negara tersebut memiliki kebebasan dalam mengelola setiap lembaga peradilannya tanpa adanya intervensi baik dari pihak luar atau pihak dalam Terkait independen dalam penegakan hukum diberikan kepada setiap aparat penegak hukum tanpa terkecuali. Secara khusus hakim sebagai penegak hukum yang memiliki kewenangan untuk memeriksa dan mengadili memiliki kewenangan secara khusus dan juga tanpa keterikatan dari pihak manapun baik secara politis maupun secara eksekutif. Kekuaaan kehakiman saat ini dibawah kekuasaan yudikatif, yang mana kekuasaan yudikatif bersifat mandiri dan bebas dari pengaruh kekuasaan dan juga tidak terikat dengan kepentingan politik manapun. ${ }^{8}$ Dengan kata lain menunjukkan bahwa independensi ini terkait dengan kebebasan yang didapatkan oleh seorang penegak hukum tanpa melihat siapa orang yang akan di hadapinya.

Independensi yang diberikan kepada lembaga Kekuasaan Kehakiman sebenarnya menjadi syarat bahwa negara Indonesia adalah negara hukum. Berbicara hukum haruslah sesuai dengan nilai kebenaran dan keadilan. Kebenaran berupa putusan yang diberikan haruslah berdasarkan fakta yang ada, sedangkan keadilan bersumber dari putusan yang dijatuhkan memiliki nilai adil bagi masyarakat sebagai korban dan pelaku kejahatannya.

Alasan adanya pemisahan kekuasaan eksekutif, legislatif dan yudikatif adalah supaya setiap lembaga kekuasaan memiliki kemandiriannya masing-masing. Montesque menyatakan alasannya yaitu jika peradilan berada dibawah lembaga yudikatif, maka setiap keputusannya memiliki hak-hak individual yang bersifat melawan keinginan negara dan lembaga negara lainnya. Penambahan argumen dari Montesque berupa: ${ }^{9}$

\footnotetext{
${ }^{8}$ Garner, Black's Law Dictionary, (USA: West Group,
} 1999), seventh edition, hlm.74

9 Ikhsan Azhar, (2018), Inkonsistensi Penerapan Prinsip Independensi Kekuasaan Kehakiman Dalam Pelaksanaan Seleksi Calon Hakim, Jurnal Vej 4 (2)

\begin{abstract}
"Keberadaan kekuasaan kehakiman diluar kekuasaan legislatif dikarenakan hakim dalam mengadili atau memutuskan perkara bukan sebagai pembuat aturan hukum, sedangkan alasan hakim diluar kekuasaan eksekutif supaya hakim tidak menjadi sebagai penindas bagi pelaku kejahatan"
\end{abstract}

Alasan inilah yang menjadi pijakan dalam menentukan kekuasaan kehakiman harus berada diluar pengaruh kekuasaan legislatif dan eksekutif. Sejalan dengan argumentasi ini, Ninian Stephen berpendapat yang dikuti dalam bukunya Djohansyah menyebutkan sebuah peradilan bisa dijalankan untuk memenuhi keadilan menurut hukum tanpa dipengaruhi oleh keputusan dan tekanan batin dari sebuah negara. ${ }^{10}$ Dengan begini dapat dipastikan bahwa Independensi bagi hakim bisa dijadikan sebagai sarana yang mudah untuk tercapainya keadilan dalam bentuk jaminan yang melindungi masyarakatnya dari tindakan melawan hukum dan tindakan kekerasan atau pengekangan dari pihak penguasa negara. pendekatan tersebut bisa menggolongkan kekuasaan kehakiman bukan berada dibawah kekuasaan eksekutif maupun legeslatif, namun kekuasaan kehakiman merupakan lembaga negara yang ada di bawah yudikatif yang bisa dijalankan secara netral tanpa ada campur tangannya dari pihak eksekutif dan juga legeslatif.

Kemandirian hakim juga di ikat dengan konstitusi negara Indonesia yang dibukukan di dalam Pasal 24 ayat (1) UUD 1945 yang menyatakan "kekuasaan kehakiman merupakan kekuasaan yang merdeka untuk menyelenggarakan peradilan guna menegakkan hukum dan keadilan". Adanya penyebutan merdeka adalah untuk memberikan kebebasan kepada hakim dalam memberikan putusannya. Bukan hanya secara konstitusi, namun kekuasaan kehakiman secara mandiri dinyatakan di dalam Universal Declaration of Human Right dan International Covenant on Civil and Political Right menyebutkan unsur-unsur yang terkandung di dalamnya berupa $^{11}$ :

1. Menghendaki adanya suatu peradilan yang di atur berdasarkan perundang-undangan

2. Peradilan itu harus memiliki kemerdekaan sendiri dan tidak memihak siapapun

3. Peradilan harus ditegakkan berdasarkan nilai kejujuran serta pemeriksaan secara terbuka untuk umum.

10 Djohansyah, Reformasi Mahkamah Agung Menuju Independensi Kekuasaan Kehakiman, Kesaint Blanc, Jakarta, 2008, tanpa halaman

${ }^{11}$ Ahmad Basuki, Pengawasan Terhadap Penyelenggaraan Kekuasaan Kehakiman Sebagai Upaya Dalam Mewujudkan Akuntabilitas Peradilan Pidana, Jurnal Perspektif, Vol. XVIII No. 1 Tahun 2013 Edisi Januari, Fakultas Hukum Universitas Wijaya Kusuma, Surabaya. 
Semua nilai yang di sampaikan dalam deklarasi hak asasi manusia lebih menekankan kepada hakim untuk menilai atau memutuskan sengketa berdasarkan nilai kemanusiaan, Sehingga hukum itu bisa memberikan keadilan kepada setiap manusia.

Secara praktek saat ini, IndIndependesi hakim untuk saat ini terlalu dibatasi oleh undang-undang. Tidak jarang banyak putusan hakim hanya mengikuti apa yang di tuntut oleh pihak kejaksaan. Seakan-akan hakim tidak memiliki kebebasan dalam menghentikan suatu dakwaan atau malah memaafkan si terdakwa. Semua ini tidak terlepas dari doktrin KUHP kolonial belanda yang merumuskan tindak pidana hanya berdasarkan legalitas formal. Sehingga terkadang hakim tidak bisa keluar dari doktrin tersebut. Jika kita perhatikan baik-baik Independensi personal hakim dilihat dengan adanya kebebasan hakim secara individu saat menghadapkan dirinya dengan suatu perkara hukum. Hakim harus memiliki kejelian dalam menghadapi permasalahan yang ada pada masyarakat, bahkan hakim dituntut untuk bisa berpikir terkait perkembangan yang ada pada masyarakat baik melalui pendekatan sosiologis maupun pendekatan virtual yang bisa didapatkan melalui sosial media. Nyatanya ketika ingin menjatuhkan sebuah keputusan yang terkait hukuman bagi si pelaku kejahatan, seorang hakim malah memiliki pertimbangan karena berdasarkan dakwaan dari si penuntut umum. Seperti sebuah contoh yang menimpa nenek minah, dimana hakim menjatuhkan putusa bersalah kepada nenek minah berdasarkan dakwaan yang dibacakan oleh penuntut umum. Seharusnya seorang hakim memiliki penilaian sendiri terkait hal tersebut. Bisa saja hakim membebaskan nenek minah dari segala tuntutan jaksa dengan melihat aspek keadilan berdasarkan hukum yang hidup dimasyarakat.

Saat ini hakim belum memiliki kebebasan yang sepenuhnya terkait independensi dalam mengadii dan memutuskan suatu perkara. Terlihat dari beberapa putusan yang terjadi selama ini, belum ada satupun hakim bisa memberikan putusan yang diluar dari tuntutan jaksa dan pembelaan dari pengacara. Berangkat dari permasalahan selama ini, hakim hanya bertugas untuk memenangi pertandingan yang dimainkan antara jaksa dan pengacara. Mengingat terlalu sempitnya ruang kebebasan hakim dalam menjatuhkan putusan, sehingga tidak jarang putusan yang dijatuhkan kepada pelaku kejahatan hanya berdasarkan tuntutan yang diberikan oleh penuntut umum tanpa melihat kondisi masyarakat setempat.

Oemar Seno Aji menulis tentang kritikannya terkait pasal 24 UUD yang berkaitan dengan kebebasan. Beliau mengatakan bahwa terkait pasal ini tampaknya tidak bevordelijk bagi perkembangan hukum saat ini. Ia kadang-kadang mempertanyakan terkait berat dan ringannya hukum yang harus dijatuhkan atau melanjutkan perkara atau dihentikan bahkan hakim tidak bisa menenangkan hati nuraninya sendiri karena harus menjatuhkan hukuman kepada seseorang meskipun tidak ada alasan yang cukup kuat untuk menghukumnya karena tidak cukup bukti atau bahkan perbuatannya merupakan suatu tindak pidana. ${ }^{12}$ semua ini tidak terlepas karena adanya gangguan dari manusia baik yang memiliki jabatan di atas atau yang berada di samping hakim tersebut. Selain itu, untuk saat ini dalam hal kebebasan hakim dalam penegakan hukum selalu dipengaruhi oleh faktor lingkungannya terumata kehidupan sosial ekonominya.

\section{Restrukturisasi Tentang Independensi Hakim Dalam Memberikan Putusan Berdasarkan Nilai-Nilai Pancasila}

Restrukturisasi dapat di artikan dalam kamus besar bahasa Indonesia yaitu penataan kembali. Penataan kembali bisa dimaknai sebagai upaya untuk memperbaiki suatu kesalahan dari sesuatu. Perbaikan bisa dari sisi pengaturan yang sudah ada saat ini, sehingga perlu ditata kembali untuk memperbaiki kekurangan yang sudah ada. Penataan ulang yang dimaksud disini adalah memperbaiki pengaturan yang terkait dalam Sistem Peradilan Pidana, khususnya pengambilan putusan hakim yang terkesan saat ini belum memiliki independensi yang kuta. Berangkat dari pengertian di atas maka bisa diartikan restrukturisasi sangat erat maknanya dengan rekonstruksi yang berarti membangun kembali system hukum pidana, khususnya berkaitan dengan pembaharuan system hukum. Ditinjau dari pembaharuan sistem hukum maka terdiri dari pembaharuan substansi, struktur dan budaya hukum. ${ }^{13}$ Mengenai sistem peradilan pidana saat ini, perlu adanya perbaikan dari nilai-nilai yang ada di dalamnya, misalkan pembahruan nilai yang bersumber dari pancasila, sehingga sistem peradilan pidana yang akan datang lebih relegius, berperikemanusiaan serta adanya nilai keadilan berdasarkan hukum yang hidup di masyarakat.

Menata kembali perlu diadakan terhadap sistem peradilan pidana supaya bisa lebih memenuhi nilai-nilai yang terkandung dalam pancasila. Sistem peradilan pidana di Indonesia sepantasnya diterapkan untuk proses penegakan hukum. ${ }^{14}$ Penegakan hukum dengan menggunakan sistem peradilan pidana biasanya ditunjukkan khususnya terhadap lembaga kekuasaan kehakiman dilakukan dengan memberikan ruang yang lebih luas terkait independensi. Kemandirian dan kemerdekaan yang dihadirkan dalam sistem peradilan

12 Andi Hamzah, Hukum Acara Pidana Indonesia, (Penerbit Sinar Grafika, Jakarta : 2016), Hlm. 101

13 Barda Nawawi Arief, RUU KUHP Baru (Sebuah Restrukturisasi/Rekontruksi Sistem Hukum Pidana Indonesia), (Semarang : Pustaka Magister Semarang, 2017), hlm. 1

14 Arief Nawawi Barda. (2019). Reformasi System Peradilan System Penegakan Hukum Di Indonesia, bahan penerbit Universitas Diponegoro, Semarang, hlm.2. 
pidana merupakan cita-cita dari suatu bangsa yang menyatakan diri sebagai negara hukum. Hukum adalah sesuatu yang sakral dari pengaruh kepentingan politk dan kekuasaan semata. Kesucian yang ada dalam hukum bisa diterapkan dengan kebebasan dan kemandirian yang diberikan terhadap lembaga kekuasaan kehakiman.

Kemandirian yang integral dalam kekuasaan kehakiman ini dimaksudkan yakni independensi didalam suatu system, ${ }^{15}$ sehingga independensi hakim tidak boleh dibatasi karena adanya undang-undang. Mengingat hakim merupakan pihak penengah diantara jaksa dan penasihat hukum. Dalam perkara pidana sebenarnya terlibat beberapa pihak. Di antaranya pihak-pihak yang saling berhadapan itu terdapat hakim yang tidak memihak dari kedua pihak yang bertingkai antara jaksa dan penasihat hukum. di dalam jaksa sebagai pihak yang mewakili korban dan juga negara, sedangkan penasihat hukum menjadi perwakilan dari terdakwa. ${ }^{16}$ Maka sangat wajar dalam penegakan hukum saat ini, banyak putusan hukuman yang diberikan hakim tidak lagi mengedepankan Independensi, dikarenakan hakim terkadang ketika memutuskan persidangan hanya melihat sesuai prosedur persidangan yang berjalan. Sehingga tidak jarang keadilan yang di hadirkan hanya sebatas keadilan prosedural bukan keadilan secara substantif. Berkenaan dengan proses peradilan tersebut maka diperlukan adanya penataan kembali terkait dengan struktur hukum dan subjek dari penegak hukum itu sendiri.

Pembaharuan budaya hukum dengan mencakup hal yang lebih komprehensif dan optimal dalam penataan ulang di budaya hukum sebagaimana telah diusung oleh Barda Nawawi Arief diantaranya ada tiga pendekatan keilmuan secara integral, diantaranya: dengan menggunakan pendekatan religious, pendekatan kontekstual dan pendekatan melalui perbandingan hukum. Pendekatan religious merupakan pendekatan utama dalam membentuk budaya hukum penegak hukum agar tetap independen, jujur, dan berintegritas. ${ }^{17}$ Pendekatan religious ini berorientasi pada pedoman ilmu dari hukum pidana dan tuntunan tuhan/religious dalam menegakkan hukum pidana. Tuntunan itu mengandung empat prinsip diantaranya prinsip persamaa (equality/non-discrimination), prinsip objektivitas (tidak subjektif), prinsip tidak pilih kasih (non-favoritisme/nonnepotisme), dan prinsip tidak berpihak (fairness/impartial).

Jika mengaju pada penataan kembali, maka bisa dilihat dari uraian yang disebutkan oleh Lawrence $\mathrm{M}$.

15 Ali, M. (2007). Sistem Peradilan Pidana Progresif; Alternatif dalam Penegakan Hukum Pidana. Jurnal Hukum IUS QUIA IUSTUM, 14(2). Hlm. 210-229.

16 Andi Hamzah, Hukum Acara Pidana Indonesia, (Penerbit Sinar Grafika, Jakarta:2016), hlm. 64

${ }^{17}$ Barda Nawawi Arief, Kapita Selekta Hukum Pidana Tentang System Peradilan Pidana Terpadu, ,hlm.52
Friedman membagi menjadi 3 komponen dalam membentuk budaya yakni: struktur, substansi dan kultur. ${ }^{18}$ Apabila dikaitkan dengan system hukum di kehakiman maka komponen struktur berkenaan dengan kelembagaan kehakiman yang ingin diciptakan itu seperti hakim yang bebas dari korupsi, independen dan mandiri serta memiliki penilaian dalam menjatuhkan pidana berdasarkan nilai-nilai yang terkadang di dalam pancasila sehingga dengan adanya patokan/tujuan yang ingin dicapai itu maka lembaga kehakiman dapat menerapkan dan dijadikan patokan agar dalam menjalankan tugas sesuai dengan wawasan pancasila. Komponen substansi adalah aspek isi dari system hukum itu sendiri yang didalamnya termaksud norma-norma dalam perwujudan peraturan perundang-undangan. Di dalam lembaga kehakiman yang dibutuhkan dalam memperbaiki strukturnya adalah memperbaiki aspek perekrutannya karena ini akan berpengaruh terhadap penegakan hukum ke depannya. Mengingat aspek perekrutan akan menentukan kebebasan dan ketidak berpihakannya terhadap sesuatu. Jika selama ini perekrutan yang dilakukan agak sedikit kurang memperhatikan aspek rohani dan juga kejujuran serta tidak dapat melihat sesuatu berdasarkan hati nuraninya. Sehingga dalam menegakkan hukum, tidak jarang penegak hukum ketika melihat kejahatan yang dilakukan langsung mencari pasal yang bisa dikenakan untuknya. Seharusnya ketika terjadi suatu kejahatan yang dilakukan terdakwa, seorang hakim harus menilainya dengan hati nurani terlebih dahulu. Misalkan hakim harus mencari dan mengetahui kalau seandainya dia memutuskan hukuman terhadap terdakwa bagaimana kondisi keluarganya atau siapa yang akan menafkahkan keluarganya lagi.

Sudah seharusnya independensi hakim berdasarkan nilai-nilai yang ada pada Pancasila. Mengingat pancasila merupakan sumber dari segala sumber hukum dan arah dalam pengambilan keputusan harus berdasarkan nilai-nilai yang terkandung di dalamnya. Sebagaimana Prof. Barda Nawawi dalam kuliahnya pernah memberikan 3 poin penting dari nilainilai yang terkandung di dalam pancasila yaitu nilai ketuhanan, kemanusian, dan demokrasi/musyawarah. ${ }^{19}$ Berdasarkan uraian tersebut, maka dapat dilihat bahwa yang perlu diperhatikan dalam memberikan putusan terhadap seseorang harus berlandaskan 3 poin penting yang terkandung di dalam pancasila tersebut. Sebagaimana dalam poin butir putusan terkandung "keadilan berdasarkan kemanusiaan yang maha esa". Prof. Barda pernah menanyakan kepada calon hakim tentang pengertian "keadilan berdasarkan ketuhanan

18 Warassih, Esmi, Pranata Hukum Sebuah Telaah Sosiologis.(Semarang: PT. Suryandaru Utama., 2005), hlm. 104.

19 Barda Nawawi Arief, Materi Kuliah Politik Hukum Pidana tahun 2019 
yang maha esa" yang dipahami oleh hakim hanya dalam memberikan putusan hanya berdasarkan keadilan yang dengan prinsip ketuhanan yang maha esa. Namun tidak mengetahui esensi dari bunyi tersebut. Padahal yang dapat dipahami dari poin tersebut dalam menegakkan keadilan berdasarkan tuntunan dari ajaran tuhan. Sebagaimana di dalam ajaran islam terkandung nilai keadilan serta nilai kemanusiaan. Keadilan yang di ajarkan tuhan yaitu sebagaimana disebutkan di dalam $\mathrm{Al}$ Qur'an yaitu 20"ketika tuhan memerintahkan keadilan tidak memandang orang tua, kerabat dekat mau kaya atau miskin tetap harus berlaku adil dan bahkan jangan sampai seorang penegak keadilan dipengaruhi oleh hafa nafsu atau kepentingan lain sehingga menyimpang dari kebenaran". Jadi seorang hakim dalam menegakkan keadilan tidak boleh mengikuti hawa nafsu atau bertindak sesuai kepentingannya saja. bahkan Allah mencela para penegak hukum yang tidak berlaku adil diakibatkan karena kebenciannya terhadap orang lain. sebagaimana disebutkan di dalam Al Qur'an yang maknanya "tegakkan hukum secara adil, jangan sampai kebencianmu terhadap sesuatu yang menjadikan kamu tidak bisa berlaku adil terhadap orang lain". ${ }^{21}$ maka yang dimaksudkan dengan keadilan berdasarkan ketuhanan yang maha esa adalah menegakkan keadilan berdasarkan ajaran agama atau bisa dikatakan sesuai dengan yang diajarkan tuhan. Dengan ajaran tersebut bisa menjadikan hakim dalam menjatuhkan pidana bisa lebih independen terhadap putusannya.

Bukan hanya dalam menegakkan keadilan yang sesuai ajaran tuhan, namun dalam menegakkan hukum juga harus berdasarkan ajaran tuhan. Misalkan ajaran dalam agama islam lebih menekankan pada aspek permaafan. Sehingga meskipun seseorang telah melakukan kejahatan dan di adili, seorang hakim dapat memutuskan secara bebas untuk menghukum atau tidak terhadap pelaku. Maka sangat dibutuhkan esensi permaafan dari hakim. di dalam bukunya Prof. Barda Nawawi mengemukakan ada 3 alasan permaafan hakim (Rechterlijk Pardon) yang bisa diberikan karena :

1. Deliknya yang terlalu ringan

2. Dilihat dari karekter pelakunya

3. Akibat perbuatan yang ditimbulkan kedepannya

Berdasarkan ketiga poin tersebut hakim bisa memberikan permaafan terhadap kejahatan yang telah dilakukan. Di dalam asas permaafan hakim ini, seorang terdakwa telah jelas melakukan kejahatannya dan terbukti secara hukum. namun hakim bisa memberikan permaafan jika melihat kejahatan yang dilakukan terlalu ringan dan bisa melihat karakter dari pelaku tersebut, serta bisa memperhatikan kerugian dari korban. Jika kerugian yang ditimbulkan telah digantikan, maka hakim bisa memberikan permaafan tersebut. Maka disinilah

\footnotetext{
${ }^{20}$ Al Qur'an surah An-Nisaa Ayat 135

${ }^{21}$ Al Qur'an Surah Al-Maidah ayat 8
}

terlihat independensi hakim yang berwawasan pancasila, karena melihat dari dari nilai ketuhanan, kemanusiaan serta musyawarah.

Selama ini penegakan hukum dan khususnya putusan yang diberikan hakim tidak berdasarkan nilainilai yang terkandung dala pancasila. Sebagaimana diketahui putusan bersalah yang diberikan kepada Mbok Minah serta orang lainnya. Karena kebebasan hakim dalam menjatuhkan putusan dibatasi oleh undangundang, sehingga hakim tidak bisa mengambil inisiatif sendiri untuk menilai suatu perkara berdasarkan nilai kemanusiaan yang ada pada dirinya. Dengan kelemahan yang diberikan dalam sistem peradilan pidana saat ini, maka sudah sewajarnya ada perbaikan serta penataan kembali terhadap independensi hakim dalam menjatuhkan putusan. Ketika ideologi para penegak hukum hanya bersandarkan pada kepastian hukum maka akan sulit ditemukan keadilan sebab kepastian hukum erat dengan keinginan untuk mempertahankan status quo. Sehingga sebagai aparat penegak hukum harus memandang hukum secara dinamis namun tetap besandar pada peraturan perundang-undangan yang berlandaskan nilai-nilai pancasila. ${ }^{22}$ serta menjadikan penegakan hukum yang berkemanusiaan dan dapat menggunakan hati nurani dalam menghukum pelaku tindak pidana.

\section{SIMPULAN}

Saat ini dalam sistem peradilan pidana masih terdapat pengekangan terhadap hakim dalam memberikan putusan bagi pelaku kejahatan. Terkait penyelesaian perkara pidana dalam sistem peradilan saat ini hanya melibatkan beberapa pihak. Hakim merupakan pihak yang harus bersikap tidak memihak di antara pihak-pihak yang lain. Penuntut umum memihak para korban dan negara, sedangkan penasihat hukum mewakili terdakwa. Namun disini peran hakim ditentukan dalam independensi dalam menjatuhkan hukuman. Realitas sekarang ini, terkadang hakim tidak memiliki kebebasan disebabkan karena terlalu terikat dengan undang-undang dan kemauan dari pihak terdakwa yang diwakili penasihat hukum dan juga korban yang diwakili oleh jaksa. Sehingga hakim terkadang tidak bisa menilai sesuatu dengan hati nuraninya sendiri. Bahkan hakim merasa gelisah dan tidak tenang ketika harus menghukum seseorang meskipun tidak ada alasan yang kuat serta tidak cukup bukti, akan tetapi hakim tetap harus menjatuhi hukum disebabkan keterikatannya dengan undang-undang. Berdasarkan dengan realita saat ini, diperlukan penataan kembali sistem peradilan pidana yang berkaitan dengan independensi yang berdasarkan nilai-nilai pancasila. Sehingga keadilan yang didapatkan bukan hanya sekedar

22 Satjipto Rahardjo, 2011. Satjipto Rahardjo Dan Hukum Progresif Urgensi Dan Kritik, (Jakarta: Epistema Institute, 2011), hlm.218. 
keadilan secara prosedural saja, namun bisa juga dihadirkan keadilan secara substansial. Penegakan hukum yang berdasarkan wawasan pancasila, berarti mengadili seseorang dengan melihat dari aspek rohani serta kemanusiaan. Terkadang hakim juga bisa memberikan permaafan kepada terdakwa berdasarkan tindak pidan yang terlalu ringan ataupun si pelaku telah menggantikan kerugian dari korban. Jadi Independensi hakim yang berdasarkan nilai-nilai pancasila lebih memberikan manfaat dan warna dalam penegakan hukum, sehingga hukum tidak terlalu kaku dan bisa mengimbangi perkembangan masyarakat.

\section{DAFTAR PUSTAKA}

Abdulkadir, Muhammad, Hukum dan Penelitian Hukum, (Bandung: PT. Citra Aditya Bakti, 2004)

Ali, M. (2007). Sistem Peradilan Pidana Progresif; Alternatif dalam Penegakan Hukum Pidana. Jurnal Hukum IUS QUIA IUSTUM, 14(2)

Arief, Barda Nawawi. 2019, Materi Kuliah Politik Hukum Pidana

Arief, Barda Nawawi, Kapita Selekta Hukum Pidana Tentang System Peradilan Pidana Terpadu,

Arief, Nawawi Barda. (2019). Reformasi System Peradilan System Penegakan Hukum Di Indonesia, bahan penerbit Universitas Diponegoro, Semarang

Arief, Barda Nawawi. 2017, RUU KUHP Baru (Sebuah Restrukturisasi/Rekontruksi Sistem Hukum Pidana Indonesia), (Semarang : Pustaka Magister Semarang)

Asshiddiqie, Jimly, Gagasan Negara Hukum Indonesia, (Jakarta, Konstitusi Press, 2005),

Atmasasmita,Romli, Sistem Peradilan Pidana(Criminal Justice System) Perspektif Eksistensialisme Dan Abolisionalisme, (Jakarta: Penerbit Bina Cipta,1996)

Basuki, Ahmad, Pengawasan Terhadap Penyelenggaraan Kekuasaan Kehakiman Sebagai Upaya Dalam Mewujudkan Akuntabilitas Peradilan Pidana, Jurnal Perspektif, Vol. XVIII No. 1 Tahun 2013 Edisi Januari, Fakultas Hukum Universitas Wijaya Kusuma, Surabaya.

Budiardjo, Miriam, Dasar-Dasar Ilmu Politik, (Jakarta: Gramedia Pustaka Utama), Edisi revisi: Cetakan kelima

Djohansyah, Reformasi Mahkamah Agung Menuju Independensi Kekuasaan Kehakiman, Kesaint Blanc, Jakarta, 2008

Garner, Black's Law Dictionary, (USA: West Group, 1999), seventh edition.

Hamzah, Andi, Hukum Acara Pidana Indonesia, (Penerbit Sinar Grafika, Jakarta : 2016)

Ikhsan, Azhar, (2018), Inkonsistensi Penerapan Prinsip Independensi Kekuasaan Kehakiman Dalam Pelaksanaan Seleksi Calon Hakim, Jurnal Vej 4 (2)
Manan, Abdul, Penemuan Hukum Oleh Hakim dalam Praktek Hukum Acara di Peradilan Agama. Makalah yang disampaikan pada Acara Rakernas Mahkamah Agung Rl tanggal 10 s/d 14 Oktober 2010, di Balikpapan, Kalimantan Timur.

Rahardjo, Satjipto, 2011. Satjipto Rahardjo Dan Hukum Progresif Urgensi Dan Kritik, (Jakarta: Epistema Institute)

Reksodiputro, Mardjono. 1993, Sistem Peradilan Pidana Indonesia (Melihat Kepada Kejahatan Dan Penegakan Hukum Dalam Batas-Batas Toleransi), (Jakarta: Fakultas Hukum Unversitas Indonesia)

Warassih, Esmi. 2005, Pranata Hukum Sebuah Telaah Sosiologis.(Semarang: PT. Suryandaru Utama)

Witanto, Darmoko Yuti dan Arya Putra Negara Kutawaringin., Diskresi Hakim Sebuah Instrumen Menegakkan Keadilan Substantif Dalam PerkaraPerkara Pidana, (Bandung, Alfabeta, 2013) 